\title{
Role of Public Service Motivation, Organization Values and Reward Expectation on Performance of Public Sector Employees in Henan, China
}

\author{
Yu-Jie Xu (Corresponding author) \\ PhD Scholar \\ INTI International University, Malaysia \\ E-mail: $874743651 @ q q . c o m$ \\ Dr. Syarifah Mastura B. Syed Abu Bakar \\ Senior Lecturer \\ INTI International University, Malaysia \\ E-mail: syarifahmas.bakar@newinti.edu.my
}

\author{
Waqas Ali \\ $\mathrm{PhD}$ Scholar \\ Limkokwing University of Creative Technology, Cyberjaya, Malaysia \\ E-mail: Waqas_ali1125@yahoo.com
}

Received: Oct. 14, 2019 Accepted: Nov. 4, 2019 Online published: Nov. 15, 2019

doi:10.5296/ijhrs.v9i4.15829 URL: https://doi.org/10.5296/ijhrs.v9i4.15829

\begin{abstract}
The main objective of this study is to investigate the role of public service motivation, organization value and reward on performance of public sector employee in the Henan, China. Data is collected from adopted instrument from earlier studies. The researcher has collected data from 396 respondents by using online survey and self-administrative collection method. For analysis of data, SPSS and SmartPLS software were used. It has been concluded that role of organization values does not have a relationship with the performance of employees. The public service motivation and reward expectation plays an important role in employee job
\end{abstract}


performance. The researcher found that earlier researchers' assumption, the non-monetary benefits in public sector job least important are not valid in context of China Public sector employees. This research concludes that the employees who are working in public sector always look for both monetary and non-monetary benefits.

Keywords: service motivation, organization values, reward expectation, performance

\section{Introduction}

Mostly people are intended to service in the public service organizations as a result have a significant impact on the society in the long term. This idea is closely connected with philosophy of public service, which describes that there is difference between public service and private sector because of nature of jobs, tasks, behavior, organizational culture, reward system etc. the study area of public service motivation is very important topic in these days. The public service can attract, retain and motivate employees who can deliver on the complex objectives of the public service (Boyle, 2012).

Currently people are motivated by many different good opportunities and considerations by government. According to Perry and Hondeghem (2008), people prefer public service organizations due to job security, career, pension system and development opportunities etc. PSM relates only to the notion that 'individuals are oriented to act in the public domain for the purpose of doing good for others and society' (Perry, Hondeghem and Wise, 2010). Vandenabeele (2008), has described that public service employee's quality of life is much better as compare to private sector, they can easily manage their family and other commitments.

In this research paper, the authors have studied the link between public service motivation, organization values, rewards and job performance in China. The public sectors in the world are facing obstacles in attracting and retaining the talent because of high quality of perks and innovative jobs in private sector. Moreover, it has been observed that in public sector employees are approximate $35 \%$ paid less than private sector. This aspect of public sector is reducing attraction the public sector jobs. Motivation towards job is most significant in the performance of any company (Fang, Luo, and Fang 2015; Kim et al. 2015; Rizaimy et al. 2018; Theurer et al. 2018). In context of China, the Chinese government is facing the attraction of talent problem in public sector. China's private sector performed very well in the last 20 years. Companies like Alibaba became famous all over the world (Tan, 2001; Huang and Gamble, 2015; Xu, 2017; Yang and He, 2017). The most prominent firms in the world like Apple started producing its product in China. As China became the center of focus of the world. The investments made in China attracted talent to private companies. Private companies offer advanced company skills and opportunities to grow. Therefore, the indication of people has changed from government jobs to private jobs.

In China's public sector there are several vacancies in threat of going unoccupied. This issue has risen in respectively of the earlier three years, with the ruling classes now calling for formerly unsuccessful applicants to go complete a second submission round to fill the unwanted posts. In different provinces currently, government departments have more than 
4,100 vacant positions without applicants (Positions are vacant and announced, applicants, are not interested). As per the responsible authorities the state administration of civil service, supervising public service and in charge of recruiting in public services' most of these announced red-collar jobs are highly desirable, as they promise job safety and benefits, and are seen as a hierarchy for rising in the specialized ladders. Similarly, China's civil service examinations, which are also known as "gaokao," are exceedingly competitive. Last year, more than $100 \%$ applicants contended for 20,700 posts — in fact, roughly 10,000 individuals competed for the receiver position at the office of the CDL China Democratic League (Hatton 2013; Wei, 2014).

At present, the tax department agencies in eleven provinces have the maximum number of unoccupied posts, with 345 new personnel needed in Sichuan southwestern China's alone. There are also problems in several central- and local-level units, including the Central Publicity Division and the Ministry of Education, as well as in the People's Bank of China. Nearly 93 percent of all posts are at the city level and village levels - the bottommost levels of the country's administrative divisions (Hatton 2013).

Employee engagement in china is very low. Only $6 \%$ in a Gallup survey said that they feel they are engaged (Yu and Srinivasan 2014). The issue is not limited to the vacant positions. The ones who are hired do not feel that they are involved. In the latest survey reported in $\mathrm{BBC}$, it is said that only $6 \%$ of Chinese personnel said they are "engaged" in their job activities, according to another survey of global Gallup survey released this month. China's numbers of employee engagement and satisfaction were equal the numbers out of war-weary Iraq. Gallup China has interviewed works across all income levels and businesses. As per the report, the employees in China are "psychologically committed to their jobs and likely to be making positive contributions to their organizations." Out of ninety-four (94) countries surveyed, only six countries scored lower rates of job engagement compared to China, including Syria, Tunisia, and Israel. The case of Syria was unique; surprisingly, 0\% of Syrians acknowledged to being engaged at their job. In a related survey, China ranked near the bottommost in a poll gauging job satisfaction among 22 Asian countries. Only $49 \%$ of Chinese respondents said they were happy and engaged in their jobs. Part of the problem, as per $\mathrm{BBC}$ report research is that very few people in China have the extravagance of following a career that sincerely interests them. Even university graduates often feel they have no choice but to opt for positions with the government or state-run enterprises since those jobs are supposed to be stable and recession-proof. This situation makes those who are happy at work in China very difficult to find (Hatton 2013).

Another official Jiang Si, who work in State Administration of taxation department in eastern China's Zhejiang province, said that Sixth Tone that the government's new salary reforms which were done in 2014 pushed for a "reasonable" salary structure that effectually dropped wages, might be one of the reasons that the public sector government jobs have become unappealing to many people. He agreed that there is another side of it too. It has also been observed some people are shifting from the public sector to private jobs because the private sector is offering attractive opportunities (Hatton 2013). 
Many studies have proposed and approved that there is a connection between employees' performance and public service motivation in public sector (Rainey, 1982; Brewer and Selden, 1998; Naff and Crum, 1999), but there are also few studies which show insignificant relationship in the employees' performance and public service motivation in public sector (Wright \& Pandey, 2008). There are only few studies which have tested direct impact of public service motivation on employee's performance, so in this study we are trying to identify that public service motivation impact along with organizational values and reward expectations.

In the publication sector motivation job performance work of Alonso and Lewis (2001) is one most comprehensive works in literature. Earlier Perry and Wise (1990) conduct research on motivation behind selecting the public sector job. The researcher concluded that the employee who is motivated for public sector job give more weight to inspiration and motivation. More as per Perry and Wise (1990), some people are more attracted towards the goal of self-achievement. They are general interest in duty or public service. Some people interested in policymaking and making an impact. As the research of Perry and wise the people who public service motivation interest area least focused on the monetary incentives.

The idea of the research paper is, if these hypotheses are correct then it will help the Chinese public sector policymakers to attract new employees. If a public sector motivated employee gets the compensation and encouragement which is a win situation for the employees. In literature in context of China, there are least studied which focused on public sector motivation while hiring the public sector employees. Moreover, in this research, the researchers are testing the impact of organization values and rewards on job performance of an employees in public sector of China. Another objective of the current study is to investigate the validity and generalizability of scale which is already established and tested in different regions of the world, through which individual public service motivation may affect work attitudes in an administrative or public organization

\section{Literature Review}

Job performance and job satisfaction are widely studied topics in literature. In literature it has been proved in many studies that gratitude leads to positive experience. In personal relationship literature which is linked with the job performance and job satisfaction the researchers have concluded the correlation between life satisfaction and Performance of employees. In this context Cortini et al., (2019), studied the public sector employee's behavior, performance, and contribution of gratitude towards it. The researcher has studied nine employees from different companies and made a conceptual framework, that framework-based questionnaire, later on, was filled by 96 public administration employees in Italy. The researcher concluded that gratitude predicts job performance. The researcher also concluded that gratitude has a practical implication on job satisfaction and job performance of public sector motivation. This gratitude also helps in maintaining the long-term sustainable performance.

Kantabutra (2019) proposed a theory of sustainability for future study based on the earlier studies, the theory provides direction to future researchers. Hu et al. (2019) proposed that the 
past performance of employees has an impact on their organization inspirations. The study was conducted in USA, and it concluded the organization environment plays an important role between past performance of employees and organization performance. Awuzie and Abuzeinab (2019) studied the suitable performance in the context of higher education. In higher education companies are investing a lot on higher education institutions and development institution to find ways of sustainable performance.

Public sector employees have more ethics in serving the public compared to private sector employees. The people who are motivated to serve the public are more likely to join the public sector organization. However, there are studies which also say the public sector employees does not serve employees better than private-sector Buchanan (1974). Therefore, this aspect of public and private sector needs further study. Also keeping in view, the context of culture, the role of public and private sector can have an impact on employees' behavior. Although many authors have examined the differences between private and public sector employees, job satisfaction and behavior (e.g., Baldwin, 1984; Lewis, 1991; Wittmer, 1991), out of these researchers very few studied the Public sector and job performance only Crowson (1997). In context of China, the author could not find any studies. Many studies have concluded that public sector employees are more committed than private-sector employees (Naff and Crum, 1999).

As per Lawler (1990), and Shafritz, Riccucci, Rosenbloom, and Hyde (1992), Work performance is difficult to measure in sophisticated office jobs. There are very few organizations which measure the performance of employees, particularly in public sector. The performance perimeter used in measuring employee performance also has certain flaws. It is expected from the performance measurement, that should give better forecast for the future of the companies and employee performance, however, least is delivered by these indicators. Even the rewards which are given on performance ratings has least impact on the employees.

Perry and Wise (1990), and Shin and Hyun (2019), also theorized that public companies with many high Public Service Motivation (PSM) employees would rely less on utilitarian (monetary \& physical) incentives. The researchers were of point of view that the utilitarian compensation systems work in private companies or institutes, where employees are mainly driven by logical choices. Some researchers also say that this kind of rewards has opposite impact on employees' performance. The employees can get attracted or involved in public or may involve in type of activities which are not as per the standard operating procedure of public sector organizations. (e.g., Deci, 1975 and Kohn, 1993). Several researches also criticize the merit pay in the government organization, because its implication is difficult. Also, in government organization, the same pay increase can impact on performance of the employees. If employees are rewarded with the same increment, the people with public service intention will perform only those who have high public service motivation. The ones with monetary benefits in mind might get discouraged (Perry, 1991). The public service can be made competitive through promotions, rewards but through these studies we can argue that public service motivation has an impact on employees' performance.

According to Hafiza et al. (2011), there are several factors that can affect employee performance like training and development opportunities, working conditions, 


\section{Macrothink}

International Journal of Human Resource Studies

ISSN 2162-3058

2019, Vol. 9, No. 4

worker-employer relationship, job security and company over all policies and procedures for rewarding employees. Among the factors that affect employee performance, motivation that comes with rewards is of utmost importance (Carraher, Gibbson \& Buckley, 2006).

\subsection{Conceptual Framework of the Study}

The previous studies focused on the public sector motivation and its impact on employees' performance. For employees' performance, other aspects like reward and organizational values have been ignored by researchers. Therefore, in this study, the author has focused on organizational values and reward as well.

According to Wright (2008), it is also possible that the consequences of public service motivation may be moderated by other factors like education. So, in this study we are using education as a moderating variable between independents and dependent variable.

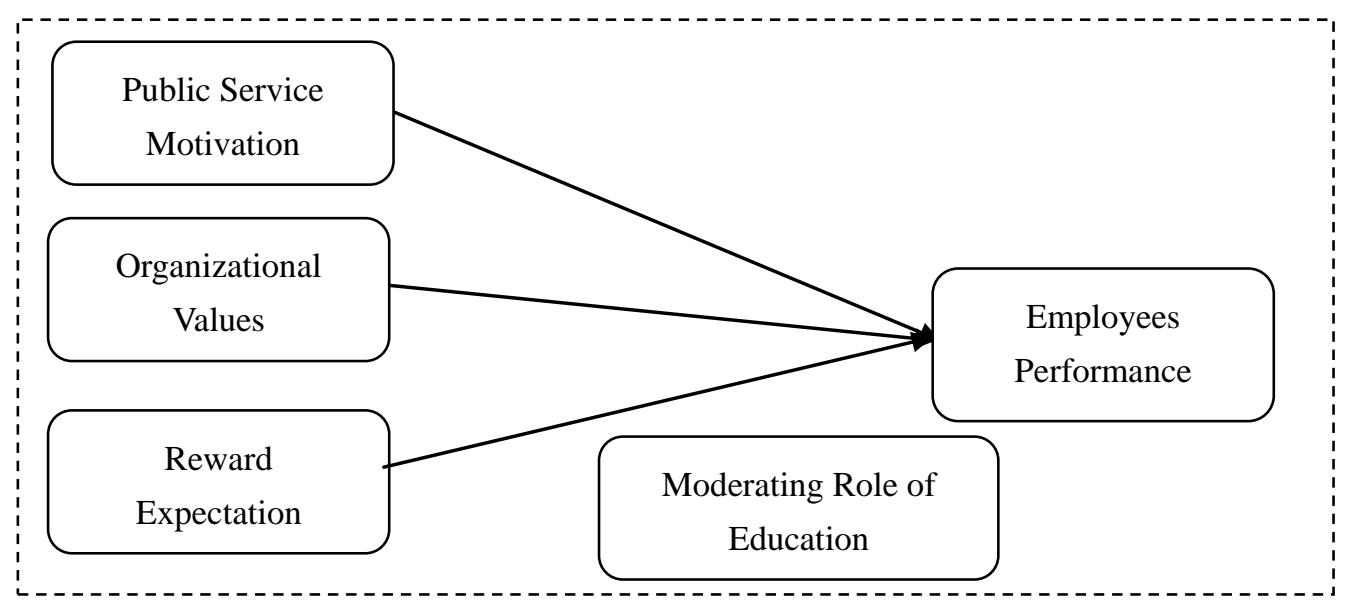

Figure 1. Conceptual Framework of the Study

\subsection{Hypotheses of the Study}

H1: Public Service Motivation has positive and significant impact on Employees Performance.

H2: Organizational Values have positive and significant impact on Employees Performance.

H3: Reward Expectation has positive and significant impact on Employees Performance.

H4: Education moderates the relationship between Public Service Motivation has positive and Employees Performance.

H5: Education moderates the relationship between Organizational Values and Employees Performance.

H6: Education moderates the relationship between Reward Expectation and Employees Performance. 


\section{Methodology}

\subsection{Sampling}

The population of the study employees of the public sector in Henan Province of China. For the selection of sample of the study the author has used the G-power software, total sample recommended for the study was from the population was 130, but we have gathered 396 final responses (3 times more than needed) to increase the accuracy of our model which is already done in earlier studies (Farooq, Khalil-Ur-Rehman, et al. 2019).

\subsection{Data Collection}

For data collection, the researcher has designed online questionnaire using in Email forms and hard copy, as most the respondents prefer to use their mobile to share the feedback as per their current time. The author also shared the physical copies of the instrument so that the respondents, if willing to can share the physical copy response. During May'19 to July'19, the authors have collected 453 respondent's responses, in which 57 responses were discarded as the respondents did not provide the complete information. As the survey was online and self-administrative, therefore the response rate was $87 \%$.

\subsection{Measurement}

To measure the public sector motivation and sustainable performance of employees the researcher has adopted the questionnaire from studies of (Alonso \& Lewis 2001; Cheah, li, \& Ho 2019; Manzoor et al. 2019). The distributed questionnaire was consisting of two sections. In the first section, the researcher collected the respondent's information. The information included the education, age and gender and years of experience in public sector. In the second section, respondents were asked questions related to public service motivation, organizational values, reward and performance of the public sector employees.

\section{Results and Analysis}

\subsection{Descritive Statistics}

The data sheet is prepared by using SPSS 21, after compiling the sheet the results were analyzed by using SPSS and SmartPLS software. The responses initial screening and the removal of outliers were done using SPSS. Descriptive statistics, demographics analysis, reliability analysis, correlation analysis, regression and moderation tests were used to analyze the results of the study. Below table shows descriptive statistics of the respondents.

Table 1. Descriptive of the Study

\begin{tabular}{lc}
\hline Public Service Motivation & Mean \\
\hline I Always look for purpose full public sector tasks. & 4.7 \\
\hline I am not afraid to go beyond my limits to serve public. & 3.2 \\
\hline I believe making society better is always better than working for & 3.4 \\
\hline \begin{tabular}{l} 
oneself. \\
\hline
\end{tabular}
\end{tabular}


I believe, in society, we are depended to each other. Therefore, the 3.6 public sector job makes me happy.

Organization Values

My organization promotes and encourage employees who like the 3.6 public.

For my organization humanity is above everything. 3.4

My organization looks for courtesy and kindness in new hires. 3.3

$\begin{array}{ll}\text { My organization makes the decisions on merit. } & 3.3\end{array}$

My organizations care about values of the other organization while 3.2

doing any business.

\begin{tabular}{ll}
\hline Reward Expectations & \\
\hline If I perform well, I expect pair raise. & 3.1 \\
\hline I like the cash benefits compared to other benefits. & 3.7 \\
\hline High performing employees are rewarded well in my organization. & 3.3 \\
\hline Low performing employees are discouraged in the organization. & 3.1 \\
\hline Employees Performance & \\
\hline Overall my work Performance is good. & 4.1 \\
\hline I receive appreciation from the people around me. & 3.5 \\
\hline I always appreciate people around me for better work. & 4.2 \\
\hline I will keep performing as per my expectations. & 3.9 \\
\hline
\end{tabular}

The above table 1 show the descriptive statistics of each item of the questionnaire, each item was measure at 5-point Likert scale where $1=$ strongly disagreed, $2=$ disagreed, $3=$ neutral, $4=$ agreed and 5 was strongly agreed. The results show that all items values mean value is greater than 3, respondents' response is toward agreed and strongly agreed recommended by (Ghulam et al., 2019).

\subsection{Demographics Profile}

The below table 2 shows the demographics profile of the respondents of study. Out of total $396,54 \%$ respondents were male and $46 \%$ female respondents participated in the current study. In terms of age of respondents who responded to the questionnaire, $30 \%$ respondents were 20 years to 25 years old and $60 \%$ respondents were 26 years to 35 years old, hence $90 \%$ of the selected sample is from 20 to 35 years age respondents. The researcher has also collected the experience statistics of the respondents. Employees from all age groups have responded to the survey. Majority of the respondents (30\%) job experience is less than 1 year and $25 \%$ respondents have only 1 to 2 years job experience. Majority of the respondents have associate, bachelor and master's degree, who have participated in the current research. 
Table 2. Demographic Profile

\begin{tabular}{lll}
\hline Gender & Count of Respondents & \% \\
\hline Male & 214 & $54 \%$ \\
Female & 182 & $46 \%$ \\
Total & 396 & $100 \%$ \\
\hline Age & Count of Respondents & \% \\
\hline 20 to 25 & 118 & $30 \%$ \\
26 to 35 & 238 & $60 \%$ \\
36 to 45 & 32 & $8 \%$ \\
46 and Above & 08 & $2 \%$ \\
Total & 396 & $100 \%$ \\
\hline Years of Experience & Count of respondents & \% \\
\hline$<1$ Year & 118 & $30 \%$ \\
1-2 Years & 99 & $25 \%$ \\
3-4 Years & 84 & $21 \%$ \\
$4-5$ Years & 51 & $13 \%$ \\
5-8 years & 20 & $5 \%$ \\
8-10 Years & 12 & $3 \%$ \\
More Than 10 Years & 12 & $3 \%$ \\
Total & 396 & $100 \%$ \\
\hline Education & 103 & $\mathbf{\%}$ \\
\hline Associate degree & 174 & $26 \%$ \\
Bachelor's degree & 396 & $44 \%$ \\
Master's degree & & $27 \%$ \\
Doctor's degree & 107 & $3 \%$ \\
Total & $100 \%$ \\
\hline
\end{tabular}

\subsection{Constructs Validity}

The below table 3 shows the construct validity of each variable with respected items. SmartPLS is extensively used social sciences for validity and SEM purpose (Abdurrahaman et al., 2018; Abdurrahaman \& Osman, 2017; Anjum et al., 2018; W. Ali, Javaid, Ali, Akram, \& Haq, 2019), Outer loading column show the loading value of each item with its variable, loading threshold is $>0.70$ (Sarstedt, Ringle, and Hair 2017), if value is below $<0.70$ it will be considered weak item for respective variable. In our study all variables items values are $>0.70$ so we are considering all items of scale for further analysis. In the next column Cronbach's alpha (reliability) value is reported, overall reliability value should be greater than 0.70 


\section{Macrothink}

International Journal of Human Resource Studies

ISSN 2162-3058

2019, Vol. 9, No. 4

(Sarstedt, Ringle, and Hair 2017), in our study all variables reliability is $>0.80$ which shows consistence in the responses. AVE value is $>0.50$ considered a good value, in our results, AVE values are greater than benchmark 0.50 (Sarstedt, Ringle, and Hair 2017).

The $\mathrm{R}^{2}$ value shows the impact of independent variables on the dependent variable. The combined effect of the independent variables of this study (Public Service Motivation, organizational values, Reward Expectations and Employees Performance) is 63\% on the dependent variable.

Table 3. Construct Validity

\begin{tabular}{|c|c|c|c|}
\hline Items & $\begin{array}{c}\text { Outer } \\
\text { Loadings }\end{array}$ & $\begin{array}{l}\text { Cronbach's } \\
\text { Alpha }\end{array}$ & AVE \\
\hline Public Service Motivation & & 0.88 & 0.56 \\
\hline $\begin{array}{l}\text { I Always look for purpose full public sector } \\
\text { tasks. }\end{array}$ & 0.81 & & \\
\hline $\begin{array}{l}\text { I am not afraid to go beyond my limits to } \\
\text { serve public. }\end{array}$ & 0.85 & & \\
\hline $\begin{array}{l}\text { I believe making society better is always } \\
\text { better than working for oneself. }\end{array}$ & 0.89 & & \\
\hline I can make sacrifices to serve the public. & 0.74 & & \\
\hline $\begin{array}{l}\text { I believe, in society, we are depended to each } \\
\text { other. Therefore, the public sector job makes } \\
\text { me happy. }\end{array}$ & 0.83 & & \\
\hline Organization Values & & $\mathbf{0 . 8 3}$ & 0.52 \\
\hline $\begin{array}{l}\text { My organization promotes and encourage } \\
\text { employees who like the public. }\end{array}$ & 0.81 & & \\
\hline $\begin{array}{l}\text { For my organization humanity is above } \\
\text { everything. }\end{array}$ & 0.83 & & \\
\hline $\begin{array}{l}\text { My organization looks for courtesy and } \\
\text { kindness in new hires. }\end{array}$ & 0.77 & & \\
\hline $\begin{array}{l}\text { My organization makes the decisions on } \\
\text { merit. }\end{array}$ & 0.85 & & \\
\hline $\begin{array}{l}\text { My organizations care about values of the } \\
\text { other organization while doing any business. }\end{array}$ & 0.82 & & \\
\hline Reward Expectations & & $\mathbf{0 . 8 9}$ & 0.55 \\
\hline If I perform well, I expect pair raise. & 0.86 & & \\
\hline $\begin{array}{l}\text { I like the cash benefits compared to other } \\
\text { benefits. }\end{array}$ & 0.83 & & \\
\hline $\begin{array}{l}\text { High performing employees are rewarded } \\
\text { well in my organization. }\end{array}$ & 0.86 & & \\
\hline $\begin{array}{l}\text { Low performing employees are discouraged } \\
\text { in the organization. }\end{array}$ & 0.88 & & \\
\hline Employees Performance & & 0.91 & 0.58 \\
\hline Overall my work Performance is good. & 0.86 & & \\
\hline I receive appreciation from the people & 0.90 & & \\
\hline
\end{tabular}


around me.

I always appreciate people around me for 0.85

better work.

I will keep performing as per my 0.88

expectations.

\subsection{Correlation Analysis}

Table 4 shows the correlation analysis of the present study variables by using SPSS. The results highlight the relationships of each variable with other variables. Further, it shows the interrelationships between variables exist or not. The Pearson R correlation results highlight the correlation of variables whether positive or negative. Table 4 shows that all the present study variables are positively correlated. The correlation values are significant at the 0.01 level. Only organizational values and employee's performance has weak correlations which is significant at 0.05 level.

Table 4. Correlation Analysis

\section{Public Service Motivation Organization Values Reward Expectations}

\begin{tabular}{llll}
\hline Organization Values & $0.53 * *$ & & \\
\hline Reward Expectations & $0.49 * *$ & $0.52 * *$ & \\
\hline Employees Performance & $0.62 * *$ & $0.17 *$ & $0.68 * *$ \\
\hline
\end{tabular}

**. Correlation is significant at the 0.01 level (2-tailed).

*. Correlation is significant at the 0.05 level (2-tailed).

4.6 Regression Analysis

The above figure depicts the impact of independent variables on dependent variables. Public service motivation, organizational values and reward expectations are independent variables however employee's performance is dependent variables. The result shows that public service motivation has positive and significant impact on employee's performance (Coefficient $=$ $0.499, \mathrm{p}=<0.05$ ), organizational value has insignificant impact on employees performance (Coefficient $=0.023, \mathrm{p}=>0.05$ ) and reward expectation has positive and significant impact on employees performance (Coefficient $=0.391, \mathrm{p}=<0.05$ ).

Table 5. Regression Analysis Path Coefficient

\begin{tabular}{lcccc}
\hline & Coefficient & T Values & P Values & $\begin{array}{c}\text { Hypothesis } \\
\text { Decision }\end{array}$ \\
\hline Public Service Motivation -> Employees Performance & 0.499 & 11.146 & 0.000 & Accepted \\
Organizational Values -> Employees Performance & 0.023 & 1.249 & 0.079 & Rejected \\
Reward Expectations -> Employees Performance & 0.391 & 7.564 & 0.000 & Accepted \\
\hline
\end{tabular}




\section{Macrothink}

International Journal of Human Resource Studies

ISSN 2162-3058 2019, Vol. 9, No. 4

The below figure shows the results of moderation analysis by using SmartPLS software. In this study, public service motivation, organizational values, reward expectation were independent variable, employee's performance was used as dependent variable and education as moderating variable. We are not testing organizational values relationship with moderating variable because the direct impact of organizational values is insignificant at employees' performance.

The results shows public service motivation has significant impact on employees performance $($ coefficient $=.286, \mathrm{p}<0.05$ ), reward also has significant impact on employees performance (coefficient $=.213, \mathrm{p}<0.0$ ), whereas moderating effect of education has significant impact between public service motivation and employees performance (coefficient $=.610, \mathrm{p}<0.05$ ), reward expectations and employees performance (coefficient $=.431$, $\mathrm{p}<0.05)$.

Based on these values we can say that moderating variable has significant impact on dependent variable. Moderating effect also has significant impact on dependent variable, independent variable in the presence of moderating variable and moderating effect (interaction term) has also significant impact on dependent variable. So, we can conclude that our finding support moderation of education between public service motivation and reward expectations on employee performance. $\mathrm{R}$ square value of model is 0.593 and all relationships have positive and significant impact.

Table 6. Moderation Analysis Path Coefficient

\begin{tabular}{|c|c|c|c|c|c|}
\hline & Coefficient & St. Error & T Value & $\begin{array}{c}\mathbf{P} \\
\text { Value }\end{array}$ & Hypothesis Decision \\
\hline Public Service Motivation -> Employees Performance & 0.286 & 0.024 & 8.396 & 0.000 & Accepted \\
\hline Reward Expectations -> Employees Performance & 0.213 & 0.040 & 5.400 & 0.000 & Accepted \\
\hline Education -> Employees Performance & 0.325 & 0.029 & 10.400 & 0.000 & Accepted \\
\hline Public Service Motivation x Education -> Employees Performance & 0.610 & 0.032 & 19.313 & 0.000 & Accepted \\
\hline Reward Expectation x Education -> Employees Performance & 0.431 & 0.037 & 14.529 & 0.000 & Accepted \\
\hline
\end{tabular}

\section{Conclusion and Recommendations}

Based on results, it has been concluded that the most critical factors in public sector employees' performance are public service motivation and the reward. Organizational values have least importance for employee performance. Building an environment of the Public sector organizations matter a lot to the employees. Therefore some of the countries have improved their Public sector organizations recently. The education plays an importance role as a moderating variable between public service motivation, reward expectations and employees' performance in the public organizations in the China. Previous studies also identified that performance-based incentives are more problematic issue in the public sector than in the private sector. 
In all organizations, motivated employees are preferred because these are cornerstone of any organization. Motivation of work is more concerned for both employees and managers of the organization. The motivation of an employee shows that how much a government serving employee wants to serve on the public interest emphasizes on individual responsibility for the nation and society. It is not difficult to understand the employees' behavior on the basis of their motivation, reward and organizational values, the level of performance will be changed with the change of these factors. Making public policy is commonly thought to be a critical work in the social development, a glorious accountability of politicians and it is also the main attraction that so many talented youths in China work for government.

\subsection{Managerial and Theoretical Contribution}

Public Sector Organizations resources must be readily accessible to all employees. All factors are essential for employees' performance of public sector employees. Top priority should be given to rewards followed Reward Expectations. Education plays a moderating role between Public Service Motivation, Reward and Employees performance, to improve education level, the government should focus on this sector.

Motivation and reward have direct link with each other, it is very necessary for the employers/mangers to reward the employee's extra efforts through incentives immediately as a show of appreciation. The Chinese government should carefully design a reward system to motive the employees of private and public sector which will give the country a competitive edge.

\subsection{Limitations and Future Directions}

This study's core objective was to empirically investigate the factors that have an impact on employees' performance of public sector employees. For future researchers, it is suggested to make a comparison of requirements between public and private sector employees. Future researchers can also compare different provinces and countries. Interest in Public Service Motivation (PSM) has grown significantly in recent years among practitioners and scholars, as well as many desires to use the concept of PSM to improve the selection, retention, and performance of public employees, so we can use this variable in the future studies.

\section{References}

Abdurrahaman, D. T., \& Osman, Z. (2017). Development of conceptual framework for Nigerian generation Y-ers' purchase intention and response towards indigenous celebrity-endorsed products: A PLS-SEM study on selected mobile service providers in Nigeria. Journal of Administrative and Business Studies, 3(1), 49-59. https://doi.org/10.20474/jabs-3.1.6

Abdurrahaman, D. T., Owusu, A., Soladoye, B. A., \& Kalimuthu, K. R. (2018). Celebrity-brand endorsement: A study on its impacts on generation y-ers in Nigeria. Asian Journal of Scientific Research, 11(3), 415-427. https://doi.org/10.3923/ajsr.2018.415.427

Ali, W., Javaid, R., Ali, S., Akram, Y., \& Haq, A. U. (2019). Influence of life events on the financial satisfaction of individuals. IBT Journal of Business Studies, 15(1), 123-137. 
Alonso, P., \& Lewis, G. B. (2001). Public service motivation and job performance: Evidence from the federal sector. The American Review of Public Administration, 31(4), 363-380. https://doi.org/10.1177/02750740122064992

Anjum, T., Ramzani, S. R., Farrukh, M., Raju, V., Nazar, N., \& Shahzad, I. A. (2018). Entrepreneurial Intentions of Pakistani Students: The Role of Entrepreneurial Education, Creativity Disposition, Invention Passion \& Passion for Founding. Journal of Management Research, 10(3), 76-100. https://doi.org/10.5296/jmr.v10i3.13253

Awuzie, B. O., \& Abuzeinab, A. (2019). Modelling Organisational Factors Influencing Sustainable Development Implementation Performance in Higher Education Institutions: An Interpretative Structural Modelling (ISM) Approach. Sustainability, 11(16), 4312. https://doi.org/10.3390/su11164312

Baldwin, N. (1984). Are we really lazy?. Review of Public Personnel Administration, 4(2), 80-89.

Boyle R. (2012). Public Service Trends 2012. Dublin: Institute of Public Administration.

Brewer, G. A., \& Selden, S. C. (1998). Whistle Blowers in the Federal Civil Service: New Evidence of the Public Service Ethic. Journal of Public Administration Research and Theory, 8(3), 413-440. https://doi.org/10.1093/oxfordjournals.jpart.a024390

Buchanan, B. (1974). Government managers, business executives, and organizational commitment. Public Administration Review, 34(4), 339-347. https://doi.org/10.2307/975244

Carraher, R., Gibson, A., \& Buckley, R (2006). Compensation in the Baltic and the USA. Baltic Journal of Management, 1, 7-23. https://doi.org/10.1108/17465260610640840

Cheah, S., \& Ho, Y. P. (2019). Mutual Support, Role Breadth Self-Efficacy, and Sustainable Job Performance of Workers in Young Firms. Sustainability, 11(12), 3333. https://doi.org/10.3390/su11123333

Cortini, M., Converso, D., Galanti, T., Di Fiore, T., Di Domenico, A., \& Fantinelli, S. (2019). Gratitude at Work Works! A Mix-Method Study on Different Dimensions of Gratitude, Job Satisfaction, and Job Performance. Sustainability, 11(14), 3902. https://doi.org/10.3390/su11143902

Crowson, P. E. (1997). Public service motivation: Building empirical evidence of incidence and effect. Journal of Public Administration Research and Theory, 4, 499-518. https://doi.org/10.1093/oxfordjournals.jpart.a024363

Deci, E. L. (1975). Intrinsic motivation. New York: Plenum. https://doi.org/10.1007/978-1-4613-4446-9

Fang, P., Luo, Z., \& Fang, Z. (2015). What is the job satisfaction and active participation of medical staff in public hospital reform: a study in Hubei province of China. Human resources for health, 13(1), 34. https://doi.org/10.1186/s12960-015-0026-2 


\section{Macrothink}

International Journal of Human Resource Studies

ISSN 2162-3058

2019, Vol. 9, No. 4

Farooq, M., Khalil-Ur-Rehman, F., Tijjani, A. D., Younas, W., Sajjad, S., \& Zreen, A. (2019). Service Quality Analysis of Private Universities Libraries in Malaysia in the Era of Transformative Marketing. International Journal for Quality Research, 13(2). https://doi.org/10.24874/IJQR13.02-02

Ghulam, W. A., Ali, W., Ali, S., Khan, M. M., Khan, R. N. A., \& Farooq, M. (2019). Investigating Factors Influencing Brain Drain of Citizens of Azad Kashmir Pakistan. The Journal of Social Sciences Research, 5(3), 782-788. https://doi.org/10.32861/jssr.53.782.788

Hafiza, N. S., Shah, S. S., Jamsheed, H., \& Zaman, K. (2011). Relationship between rewards and employee's motivation in the non-profit organizations of Pakistan. Business Intelligence Journal, 4(2), 327-334.

Hatton, C. (2013). "Why Do Most Chinese Dislike Their Jobs? - BBC News." https://www.bbc.com/news/blogs-china-blog-25099289 (May 8, 2019).

Hu, C., Zhang, H., Song, M., \& Liang, D. (2019). Past Performance, Organizational Aspiration, and Organizational Performance: The Moderating Effect of Environmental Jolts. Sustainability, 11(15), 4217. https://doi.org/10.3390/su11154217

Huang, Q., \& Gamble, J. (2015). Social expectations, gender and job satisfaction: Front-line employees in C hina's retail sector. Human Resource Management Journal, 25(3), 331-347. https://doi.org/10.1111/1748-8583.12066

Kantabutra, S. (2019). Achieving Corporate Sustainability: Toward a Practical Theory. Sustainability, 11(15), 41-55. https://doi.org/10.3390/su11154155

Kim, C., Lee, I. S., Wang, T., \& Mirusmonov, M. (2015). Evaluating effects of mobile CRM on employees' performance. Industrial Management \& Data Systems, 115(4), 740-764. https://doi.org/10.1108/IMDS-08-2014-0245

Kohn, A. (1993). Punished by rewards: The trouble with gold stars, incentive plans, A's, praise, and other bribes. Boston: Houghton Mifflin.

Lawler, E. E. (1990). Strategic pay: Aligning organizational strategies and pay systems (pp. 70-71). San Francisco: Jossey-Bass.

Lewis, G. B. (1991). Pay and job satisfaction in the federal civil service. Review of Public Personnel Administration, 11(3), 17-31. https://doi.org/10.1177/0734371X9101100302

Manzoor, F. et al. (2019). An Examination of Sustainable HRM Practices on Job Performance: An Application of Training as a Moderator. Sustainability (Switzerland), 11(8), 1-19. https://doi.org/10.3390/su11082263

Naff, K. C., \& Crum, J. (1999). Working for America: Does Public Service Motivation Make a Difference? Review of Public Personnel Administration, 19(4), 5-16. https://doi.org/10.1177/0734371X9901900402

OECD. (2005). La Re'mune'ration Lie'e aux Performances dans l'Administration [Pay-Per Performance in Public Administrations]. Paris: OECD. 
Perry, J. L. (1991). Linking pay to performance: The controversy continues. In C. Ban \& N. M. Riccucci (Eds.), Public personnel management: Current concerns-future challenges. New York: Longman.

Perry, J. L. (1996). Measuring public service motivation: An assessment of construct Reward Expectations and validity. Journal of Public Administration Research and Theory, 6(1), 5-22. https://doi.org/10.1093/oxfordjournals.jpart.a024303

Perry, J. L., \& Wise, L. R. (1990). The motivational bases of public service. Public Administration Review, 50(3), 367-373. https://doi.org/10.2307/976618

Perry, J., \& Hondeghem, A. (2008). Motivation in Public Management: The Call of Public Service. Oxford: Oxford University Press.

Perry, J., Hondeghem, A., \& Wise, L. (2010). Revisiting the Motivational Bases of Public Service: Twenty Years of Research and an Agenda for the Future. Public Administration Review, September-October 2010. https://doi.org/10.1111/j.1540-6210.2010.02196.x

Rainey, H. G. (1982). Reward Preferences Among Public and Private Managers: In Search of the Service Ethic. American Review of Public Administration, 16(4), 288-302. https://doi.org/10.1177/027507408201600402

Rizaimy, M. et al. (2018). Determinants of ISO 9001 quality management system effectiveness amongst electrical and electronics manufacturing firms in Malaysia. International Journal for Quality Research, 12(3), 655-76.

Sarstedt, M., Christian, M. R., \& Joseph, F. H. (2017). Handbook of Market Research Partial Least Squares Structural Equation Modeling. https://doi.org/10.1007/978-3-319-05542-8_15-1

Shafritz, J. M., Riccucci, N., Rosenbloom, D. H., \& Hyde, A. C. (1992). Personnel management in gov-ernment: Politics and process (4th ed., p. 492). New York: Marcel Dekker.

Shin, L. R., \& Sunghyup, S. H. (2019). "Impact of Managerial Influence Tactics on Job Creativity and Performance: A Focus on Korean Airline Service Employees." https://doi.org/10.3390/su11164429

Tan, L. (2001). "Informatisation for / an E-Economy in China."

Theurer, C. P., Tumasjan, A., Welpe, I. M., \& Lievens, F. (2018). Employer branding: a brand equity-based literature review and research agenda. International Journal of Management Reviews, 20(1), 155-179. https://doi.org/10.1111/ijmr.12121

Vandenabeele, W. (2008). Development of a public service motivation measurement scale: Corroborating and extending Perry's measurement instrument. International public management journal, 11(1), 143-167. https://doi.org/10.1080/10967490801887970

Wei, G. (2014). "Chinese Officials Are Fleeing the Public Sector for the Private Sector WSJ." 
https://www.wsj.com/articles/chinese-officials-are-fleeing-the-public-sector-for-the-private-se ctor-1409835345 (May 6, 2019).

Wittmer, D. (1991). Serving the people or serving for pay: Reward preferences among government, hybrid sector, and business managers. Public Productivity and Management Review, 14(4), 369-383. https://doi.org/10.2307/3380953

Wright, B. (2008). Methodological Challenges Associated with Public Service Motivation Research. In Perry J. and Hondeghem A. Motivation in Public Management: the Call of Public Service. Oxford: Oxford University Press.

Wright, B. E., \& Pandey, S. K. (2008). Public Service Motivation and the Assumption of Person-Organization Fit Testing the Mediating Effect of Value Congruence. Administration \& Society, 40(5), 502-521. https://doi.org/10.1177/0095399708320187

Xu, J. (2017). Contentious Space and Scale Politics: Planning for Intercity Railway in China's Mega-City Regions. Asia Pacific Viewpoint, 58(1), 57-73. https://doi.org/10.1111/apv.12142

Yang, C., \& He, C. (2017). Transformation of China's 'World Factory': Production Relocation and Export Evolution of the Electronics Firms. Tijdschrift voor economische en sociale geografie, 108(5), 571-591. https://doi.org/10.1111/tesg.12222

Yu, D., \& Rajesh, S. (2014). Employee Engagement Increases in China, but Still Very Low. Gallup. https://news.gallup.com/poll/160190/employee-engagement-increases-china-low.aspx (May 11, 2019).

\section{Copyright Disclaimer}

Copyright for this article is retained by the author(s), with first publication rights granted to the journal.

This is an open-access article distributed under the terms and conditions of the Creative Commons Attribution license (http://creativecommons.org/licenses/by/4.0/). 